\title{
Impacts of Agricultural Areas on Spatio-Temporal Variability of Daily Minimum Extreme Flows during the Transitional Seasons (Spring and Fall) in Southern Quebec
}

\author{
Ali Arkamose Assani ${ }^{1, *(D)}$, Ayoub Zeroual ${ }^{2}\left(\mathbb{D}\right.$, Alexandre Roy ${ }^{1,3}$ and Christophe Kinnard ${ }^{1}$ (D) \\ 1 Department of Environmental Sciences and Research Centre for Watershed-Aquatic Ecosystem \\ Interactions (RIVE, UQTR), University of Quebec at Trois-Rivières, 3351 Boulevard des Forges, \\ Trois-Rivières, QC G9A 5H7, Canada; Alexandre.Roy@uqtr.ca (A.R.); Christophe.Kinnard@uqtr.ca (C.K.) \\ 2 Higher National School of Hydraulics, Blida 09000, Algeria; zeroualayoub34@yahoo.fr \\ 3 Centre d'Applications et de Recherches en Télédétection (CARTEL), Université de Sherbrooke, \\ Sherbrooke, QC J1K 2R1, Canada \\ * Correspondence: Ali.Assani@uqtr.ca
}

check for

updates

Citation: Assani, A.A.; Zeroual, A.; Roy, A.; Kinnard, C. Impacts of

Agricultural Areas on

Spatio-Temporal Variability of Daily Minimum Extreme Flows during the Transitional Seasons (Spring and Fall) in Southern Quebec. Water 2021, 13, 3487. https://doi.org/10.3390/ w13243487

Academic Editor: Maria Mimikou

Received: 29 October 2021

Accepted: 2 December 2021

Published: 7 December 2021

Publisher's Note: MDPI stays neutral with regard to jurisdictional claims in published maps and institutional affiliations.

Copyright: (c) 2021 by the authors. Licensee MDPI, Basel, Switzerland. This article is an open access article distributed under the terms and conditions of the Creative Commons Attribution (CC BY) license (https:/ / creativecommons.org/licenses/by/ $4.0 /)$.

\begin{abstract}
Several statistical methods were used to analyze the spatio-temporal variability of daily minimum extreme flows (DMEF) in 17 watersheds - divided into three homogenous hydroclimatic regions of southern Quebec — during the transitional seasons (spring and fall), during the 1930-2019 period. Regarding spatial variability, there was a clear difference between the south and north shores of the St. Lawrence River, south of $47^{\circ} \mathrm{N}$. DMEF were lower in the more agricultural watersheds on the south shore during transitional seasons compared to those on the north shore. A correlation analysis showed that this difference in flows was mainly due to more agricultural areas ((larger area $(>20 \%)$ on the south than on the north shore $(<5 \%)$ ). An analysis of the long-term trend of these flows showed that the DMEF of south-shore rivers have increased significantly since the 1960s, during the fall (October to December), due to an increase in rainfall and a reduction in cultivated land, which increased the infiltration in the region. Although there was little difference between the two shores in the spring (April to June), we observed a decrease in minimum extreme flows in half $(50 \%)$ of the south-shore rivers located north of $47^{\circ} \mathrm{N}$.
\end{abstract}

Keywords: minimum extreme flows; spring; fall; agriculture; hydrology; watersheds; infiltration; long-term trend; statistical analysis

\section{Introduction}

In cold temperate regions, the impacts of global warming on minimum river flows are relatively complex. This complexity results from the different impacts of warming on the two types of river flow feeding regimes: snowmelt and rainfall. Many studies have already shown a significant decrease in snowfall in many regions, in the current context of global warming [1-5]. As for rainfall, the impacts of warming generally result in increased rainfall in winter (increase in temperature) and in summer (increase in evapotranspiration) [6-8]. Despite numerous studies on the temporal variability of minimum flows in the context of global warming [9-26], few have focused on analyzing the impacts of these changes in seasonal precipitation regimes on minimum flows. Furthermore, the impacts of global warming on minimum flows can be amplified or mitigated by land use, particularly agriculture, as observed in a number of watersheds in certain agricultural regions of the USA $[13,27]$.

Like other cold temperate regions, the climate in Quebec regions consists primarily of two seasons: winter (cold and snowy) and summer (hot and/or rainy), and these longer seasons are bisected by two transitional seasons, spring and fall. Spring marks the transition from cold (winter) to hot (summer), while fall marks the opposite transition from hot (summer) to cold (winter). From a hydrological perspective, the sequence of the 
seasons strongly influences river flow regimes during the two transitional seasons. Spring flows are primarily influenced by snowmelt from the winter, while fall flows are primarily influenced by rainfall. As such, the factors affecting spatio-temporal flow variability during these two transitional seasons are not necessarily the same, and are not affected by global warming in the same way.

Studies in Quebec on the impacts of global warming on temperature and precipitation have shown that, in winter, these impacts mean rising temperatures and decreasing snowfall [28-30]. In summer, these impacts also mean a rise in the temperature, combined with increasing rainfall [31,32]. The hydrological impact of these changes in temperature and precipitation regimes were studied in winter and summer only [33-36]. Research conducted during the spring and fall has so far focused on the temporal variability of floods [37-39]. However, unlike the two previous seasons, these two transitional seasons are characterized by periods of high and low flows, in Quebec. In spring, low flows occur before or after snowmelt, and, in fall, after a period without rain. It is important to stress that these periods of low flow do not necessarily correspond to periods of hydrological drought. However, despite the existence of these periods of low flows, there are still no studies dedicated specifically to daily minimum extreme flows during the transitional seasons (spring and fall), despite their vital role in the function and evolution of aquatic ecosystems and human activity [40,41]. In Quebec, for example, certain indices (standards) for calculating the instream flows, to protect aquatic habitats, take these minimum flows into account in spring and in fall [42]. From a seasonal perspective, almost all previous research conducted in cold temperate regions analyzed minimum daily flows in winter and/or summer exclusively. There are no studies on minimum flows in the transitional seasons (spring and fall), and none that analyze the factors affecting these flows from a spatial perspective. Given these considerations, our study focused on the following three objectives:

1. Identify factors that influence spatial variability in daily minimum extreme flows in southern Quebec in spring (April to June) and fall (October to December). This objective is based on the hypothesis that, due to the differences in the mechanisms and processes affecting daily minimum extreme flows in the spring and fall, the factors affecting spatial variability also differ during these seasons in Quebec. It is important to remember that minimum extreme flows in spring are mainly associated with recession (surface runoff), whereas in fall they are generally associated with the direct recharge of bedrock aquifers during low-water events.

2. Compare the temporal variability, or long-term trend (stationarity of hydrological series), of daily minimum extreme flows in spring and fall. This objective is based on the hypothesis that daily minimum extreme flows decrease in spring, due to a decrease in snowfall in winter and early snowmelt, and in fall, due to increased evapotranspiration caused by higher temperatures in summer and early fall.

3. Finally, the 2010s is considered the wettest decade on record in North America. Given that this moisture caused several catastrophic floods in Quebec over the course of the decade, its impact on the evolution of daily minimum extreme flows during these seasons should be analyzed. We will test the hypothesis of whether this moisture caused a significant increase in daily minimum extreme flows in the spring and fall, in addition to flooding.

\section{Materials and Methods}

\subsection{Description of the Watersheds and Data Sources}

To test these three hypotheses, we analyzed the daily minimum extreme flows in 17 watersheds in spring and fall from 1930 to 2019. Human activity has very little impact on flow measurements. The 17 watersheds were divided into three hydroclimatic regions, defined in southern Quebec [33,37]: two on the south shore of the St. Lawrence River, and only one on the north shore (Figure 1 and Table 1). The eastern hydroclimatic region, located on the south shore, north of $47^{\circ} \mathrm{N}$, is characterized by a cold temperate maritime 
climate, whereas the climate of the southeastern hydroclimatic region, just south-east of this parallel, is mixed temperate (part continental and part maritime). The north shore hydroclimatic region is characterized by a cold temperate continental climate. The rivers on the south shore run through the Appalachians and the St. Lawrence Lowlands, becoming more scarce heading northward. These two geological formations consist mainly of sedimentary rocks. The rivers on the north shore flow almost entirely on the Canadian Shield, which consists mainly of metamorphic rocks.

In hydrogeological terms, on the north shore of the St. Lawrence River, on the Canadian Shield, aquifers are located in cracks and faults in the bedrock, as well as in superficial deposits originating mainly from glaciers and rivers. On the south shore, they are found in crystalline, metamorphic, and sedimentary rock, as well as in lacustrine, glacial, marine, and river deposits covering these deep rocks. It is important to note that no studies have been done on the hydrogeological characteristics of these aquifers for southern Quebec as a whole. Existing studies only examined a few watersheds on both shores.

Physiographic variables were summarized per basin; they include mean watershed slope, drainage density, and land cover and use. Land cover and use (forest, wetland, agricultural and urban relative areas) variables were obtained from the $1.1 \mathrm{~km}$ resolution Canada land-cover database, derived from an advanced very high resolution radiometer (AVHRR) sensor operating on board the United States National Oceanic and Atmospheric Administration (NOAA) satellites. The classification was based on approximately 45 cloud free summer images, spanning the period 1988-1991.

Table 1. Rivers analyzed.

\begin{tabular}{|c|c|c|c|c|c|}
\hline Rivers & Code & $\begin{array}{c}\text { Drainage } \\
\text { Area }\left(\mathrm{Km}^{2}\right)\end{array}$ & $\begin{array}{l}\text { Latitude } \\
\text { (N) }\end{array}$ & $\begin{array}{l}\text { Longitude } \\
\text { (W) }\end{array}$ & $\begin{array}{c}\text { Agricultural } \\
\text { Area (\%) }\end{array}$ \\
\hline \multicolumn{6}{|c|}{ Southeastern Hydroclimatic Region (South Shore) } \\
\hline Chateaugay & SE1 & 2492 & $45^{\circ} 19^{\prime} 49^{\prime \prime}$ & $73^{\circ} 45^{\prime} 44^{\prime \prime}$ & 41.9 \\
\hline Eaton & SE2 & 646 & $45^{\circ} 28^{\prime} 05^{\prime \prime}$ & $71^{\circ} 39^{\prime} 18^{\prime \prime}$ & 10.7 \\
\hline Nicolet SW & SE3 & 562 & $45^{\circ} 47^{\prime} 30^{\prime \prime}$ & $71^{\circ} 58^{\prime} 05^{\prime \prime}$ & 26.3 \\
\hline Etchemin & SE4 & 1152 & $46^{\circ} 39^{\prime} 25^{\prime \prime}$ & $71^{\circ} 39^{\prime} 18^{\prime \prime}$ & 25.5 \\
\hline Beaurivage & SE5 & 708 & $46^{\circ} 39^{\prime} 25^{\prime \prime}$ & $71^{\circ} 17^{\prime} 20^{\prime \prime}$ & 34.7 \\
\hline Du Sud & SE6 & 821 & $46^{\circ} 49^{\prime} 22^{\prime \prime}$ & $70^{\circ} 45^{\prime} 22^{\prime \prime}$ & 10.4 \\
\hline \multicolumn{6}{|c|}{ Eastern Hydroclimatic Region (South Shore) } \\
\hline Ouelle & E1 & 796 & $47^{\circ} 22^{\prime} 52^{\prime \prime}$ & $67^{\circ} 57^{\prime} 14^{\prime \prime}$ & 2.8 \\
\hline Du Loup & E2 & 1042 & $47^{\circ} 36^{\prime} 43^{\prime \prime}$ & $69^{\circ} 38^{\prime} 41^{\prime \prime}$ & 10.2 \\
\hline Trois-Pistoles & E3 & 930 & $48^{\circ} 05^{\prime} 21^{\prime \prime}$ & $69^{\circ} 11^{\prime} 43^{\prime \prime}$ & 16.5 \\
\hline Rimouski & E4 & 1615 & $48^{\circ} 24^{\prime} 46^{\prime \prime}$ & $68^{\circ} 33^{\prime} 18^{\prime \prime}$ & 8.8 \\
\hline Matane & E5 & 1665 & $48^{\circ} 46^{\prime} 25^{\prime \prime}$ & $67^{\circ} 32^{\prime} 25^{\prime \prime}$ & 8.9 \\
\hline Blanche & E6 & 223 & $48^{\circ} 47^{\prime} 20^{\prime \prime}$ & $67^{\circ} 41^{\prime} 51^{\prime \prime}$ & 30.2 \\
\hline \multicolumn{6}{|c|}{ Southernwest Hydroclimatic Region (North Shore) } \\
\hline Petite Nation & SW1 & 1331 & $45^{\circ} 47^{\prime} 27^{\prime \prime}$ & $75^{\circ} 05^{\prime} 22^{\prime \prime}$ & 0.7 \\
\hline Du Nord & SW2 & 1163 & $45^{\circ} 31^{\prime} 08^{\prime \prime}$ & $74^{\circ} 20^{\prime} 11^{\prime \prime}$ & 0.4 \\
\hline L'Assomption & SW3 & 1286 & $46^{\circ} 02^{\prime} 45^{\prime \prime}$ & $73^{\circ} 26^{\prime} 19^{\prime \prime}$ & 8.6 \\
\hline Matawin & SW4 & 1387 & $46^{\circ} 40^{\prime} 50^{\prime \prime}$ & $73^{\circ} 55^{\prime} 00^{\prime \prime}$ & 0 \\
\hline Vermillon & SW5 & 2662 & $47^{\circ} 39^{\prime} 20^{\prime \prime}$ & $72^{\circ} 57^{\prime} 44^{\prime \prime}$ & 0 \\
\hline
\end{tabular}




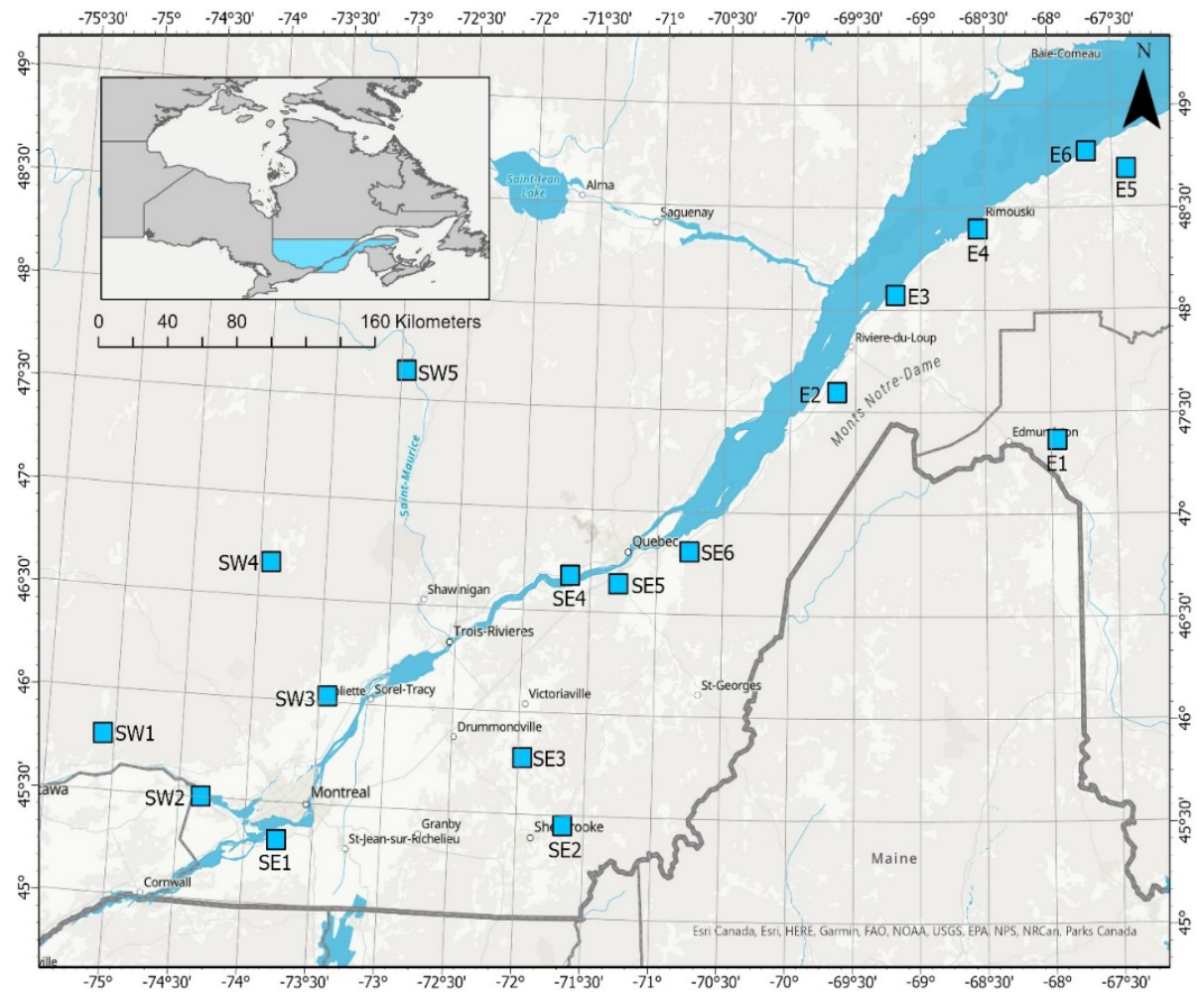

Figure 1. Location of river stations. SW = Southwestern hydroclimatic Region; SE = Southeastern Hydroclimatic Region; E = Eastern Hydroclimatic Region; the circles represent major towns.

As for watershed morphology, two key variables were measured: the mean slope of the watershed, and drainage density. These two variables were calculated using the $400 \mathrm{~m}$ resolution Canadian Digital Elevation Model (CDEM), and the drainage network produced by the Ministry of Energy and Natural Resources of Quebec (MERN). These two variables significantly influence the runoff and infiltration processes that impact minimum flows. Mean slope values of the watersheds analyzed varied between 0.46 and $3.85 \mathrm{~m} / \mathrm{km}$ on the south shore, and 2.2 and $3.75 \mathrm{~m} / \mathrm{km}$ on the north shore. Drainage density values varied between 0.33 and $0.53 \mathrm{~km} / \mathrm{km}^{2}$ on the south shore, and 0.37 and $0.49 \mathrm{~km} / \mathrm{km}^{2}$ on the north shore. Other morphological variables, such as drainage length, were strongly correlated with the surface area and/or mean slope of the watersheds.

With respect to land use, the proportion of agricultural area was greater than $10 \%$ on the south shore south of $47^{\circ} \mathrm{N}$, and below $10 \%$ on the north shore (Table 1). However, the proportion of wetland surface area was less than $5 \%$ on the south shore, but greater than $8 \%$ on the north shore (except for the watershed of the L'Assomption River, which was the most agricultural). Overall, the south shore had a smaller forest area than the north shore. There was a significant difference between the two shores, south of $47^{\circ} \mathrm{N}$. Finally, in all of the watersheds analyzed, the amount of urbanized surface area was less than $1 \%$, with the exception of the watersheds of the Chatteauguay River (43\%), on the south shore, and L'Assomption River (5\%), on the north shore. There was little water extraction from aquifers for irrigation or industry, even in the highly agricultural watersheds on the south shore.

Flow data were taken from the website of the Ministry of Environment and the Fight against Climate Change's Water expertise Centre of Quebec (https://www.cehq.gouv. qc.ca/index_en.asp, accessed on 20 February 2020). Data on physiographic variables were also kindly provided to us by the Centre. They include mean watershed slope and drainage density, as well as percentages of forest, wetland, agricultural and urbanized areas. Climate data was taken from the Environment Canada website (https: / climat.meteo.gc. ca/climate_normals/index_f.html, accessed on 18 June 2021). These are the climatic norms, 
measured at a station in each watershed during the period of 1971-2000. These climatic norms were compared to those of 1941-1970 and 1981-2010, when values were available. In the case of a difference between the three, we calculated their means. The climatic variables analyzed were seasonal precipitation and temperature.

For each of the 17 rivers under study, we created two seasonal hydrological series: spring (April to June) and fall (October to December) daily minimum extreme flows. This involved measuring the lowest flow values of one (1) day per season, each year between 1930 and 2019. We calculated the arithmetic mean (Mean) for each hydrological series and determined the maximum (Max) and minimum (Min) values.

\subsection{Statistical Analysis of the Hydrological Series}

To analyze the spatial variability of daily minimum extreme flows, we compared the arithmetic means of the hydrological series using parametric and non-parametric tests (ANOVA and Kruskal-Wallis respectively). The arithmetic means, as well as maximum and minimum flow values, were then correlated with the watersheds' physiographic and climatic factors. To ensure that watershed size would have no influence on the results, we converted these three flow variables into specific flows $\left(\mathrm{L} / \mathrm{s} / \mathrm{km}^{2}\right)$.

We used two types of tests to analyze the temporal variability of daily minimum extreme flows. The first was to analyze the long-term trend in the hydrological series using six different statistical tests based on the Mann-Kendall (MK) test. The purpose of some of these tests was to eliminate the effects of short-term persistence (STP) by removing the influence of autocorrelation (MMK-PW and TFPW), or correcting the variance introduced by autocorrelation (MMKY and MMKH). Other tests were designed to eliminate the effects of long-term persistence (LTP). Only one test (MMK-LTP) was used for this purpose. To avoid weighing down the text with formulas, all tests have been summarized in Table 2 and supplemented with references containing detailed descriptions. For more information on their mathematical descriptions and application in hydroclimatology, we direct readers to this section.

Table 2. Summary of Mann-Kendall tests applied to the hydrological series under analysis.

\begin{tabular}{|c|c|c|c|}
\hline Name of the Test & Acronym & Purpose of the Test & References \\
\hline \multicolumn{4}{|c|}{ Elimination of STP (Short Term Persistence) Effects } \\
\hline Original Mann-Kendall & MK & $\begin{array}{l}\text { Detect the long-term trend } \\
\text { (does not take STP or LTP into } \\
\text { account). }\end{array}$ & [43] \\
\hline Prewhitenning method & MMK-PW & $\begin{array}{c}\text { Eliminate the influence of } \\
\text { autocorrelation by } \\
\text { prewhitenning data. }\end{array}$ & [44] \\
\hline $\begin{array}{l}\text { Trend Free Prewhitening } \\
\text { Method }\end{array}$ & TFPW & $\begin{array}{l}\text { Eliminate autocorrelation by } \\
\text { prewhitening data. }\end{array}$ & [45] \\
\hline Modified Mann-Kendall Test1 & MMKY & $\begin{array}{l}\text { Eliminate autocorrelation by } \\
\text { variance correction. }\end{array}$ & [46] \\
\hline Modified Mann-Kendall Test2 & MMKH & $\begin{array}{l}\text { Eliminate autocorrelation by } \\
\text { variance correction. }\end{array}$ & [47] \\
\hline \multicolumn{4}{|c|}{ Elimination of LTP (Long Term persistence) Effects } \\
\hline Long Term Persistence MK & LTP & Eliminate LTP effects. & [48] \\
\hline
\end{tabular}

In the final stage of the statistical analysis, we conducted three more tests to detect shifts in the mean of the hydrological series: the Pettitt (PT) test, the modified Pettitt test (TPM), and the Lombard test (LT). While the first two tests exclusively detect abrupt shifts, the final test can detect both abrupt and gradual (smooth) shifts. Unlike the original Pettitt 
(PT) test [49], the modified Pettitt test (TPM) and the Lombard test eliminate the influence of autocorrelation on the detection of shift in mean [50-52].

\section{Results}

\subsection{Comparison of Spatial Variability of Daily Minimum Extreme Flows in Spring and Fall}

Spring and fall daily minimum extreme flow values are presented in Table 3 and Figure 2. In spring, average flow values were higher on the north shore than on the south shore. The difference between the two shores was most significant south of $47^{\circ} \mathrm{N}$, between the rivers of the southwestern hydroclimatic region $\left(>7 \mathrm{~L} / \mathrm{s} / \mathrm{km}^{2}\right)$ and those of the southeastern hydroclimatic region $\left(<6 \mathrm{~L} / \mathrm{s} / \mathrm{km}^{2}\right)$. The same applies to minimum values. This difference between the flow values of the two hydroclimatic regions of the two shores was also observed in the fall, even for maximum values.

Table 3. Comparison of seasonal minimum extreme daily flows $\left(\mathrm{L} / \mathrm{s} / \mathrm{km}^{2}\right)$ in spring and fall between 1930 and 2019.

\begin{tabular}{|c|c|c|c|c|c|c|}
\hline \multirow{2}{*}{ Rivers } & \multicolumn{3}{|c|}{ Spring } & \multicolumn{3}{|c|}{ Fall } \\
\hline & Max & Mean & Min & Max & Mean & Min \\
\hline \multicolumn{7}{|c|}{ Southeastern Hydroclimatic Region } \\
\hline Chateaugay & 9.2 & $3.3(1.61)$ & 0.56 & 9.3 & $2.6(1.74)$ & 0.28 \\
\hline Eaton & 7.0 & $3.1(1.30)$ & 0.88 & 8.1 & $3.2(1.62)$ & 0.78 \\
\hline Nicolet SW & 10.8 & $2.8(1.95)$ & 0.25 & 8.3 & $3.4(1.98)$ & 0.53 \\
\hline Etchemin & 14.1 & $3.6(2.67)$ & 0.88 & 18.1 & $4.5(2.30)$ & 1.00 \\
\hline Beaurivage & 47.3 & $3.6(4.98)$ & 0.56 & 9.5 & $3.3(1.94)$ & 0.16 \\
\hline Du Sud & 13.5 & $5.5(2.52)$ & 0.30 & 13.0 & $4.6(2.08)$ & 0.12 \\
\hline \multicolumn{7}{|c|}{ Eastern Hydroclimatic Region } \\
\hline Ouelle & 16.1 & $3.9(2.38)$ & 0.54 & 7.3 & $2.9(1.74)$ & 0.35 \\
\hline Du Loup & 13.1 & $5.8(2.42)$ & 0.71 & 11.7 & $4.3(2.43)$ & 0.27 \\
\hline Trois-Pistoles & 11.4 & $4.1(2.14)$ & 1.4 & 3.2 & $1.3(0.59)$ & 0.37 \\
\hline Rimouski & 25.4 & $6.3(3.95)$ & 1.7 & 15.9 & $4.7(2.76)$ & 0.70 \\
\hline Matane & 21.4 & $8.0(4.22)$ & 1.73 & 15.9 & 4.7 (2.77) & 0.70 \\
\hline Blanche & 21.1 & $5.2(3.43)$ & 2.0 & 18.3 & $4.1(3.75)$ & 0.38 \\
\hline \multicolumn{7}{|c|}{ Southernwest Hydroclimatic Region } \\
\hline Petite Nation & 24.3 & $9.8(4.01)$ & 3.6 & 20.9 & $4.8(3.26)$ & 1.2 \\
\hline Du Nord & 16.5 & $8.1(2.79)$ & 3.9 & 15.2 & $7.0(2.56)$ & 2.7 \\
\hline L'Assomption & 14.3 & $7.9(2.83)$ & 2.5 & 12.9 & $5.4(2.80)$ & 0.72 \\
\hline Matawin & 27.2 & $8.9(4.33)$ & 2.7 & 14.2 & $6.6(2.45)$ & 2.0 \\
\hline Vermillon & 15.6 & $7.6(3.09)$ & 2.2 & 14.4 & $6.5(2.64)$ & 1.7 \\
\hline
\end{tabular}

(1.61) = standard deviation.

Based on the analysis of correlation coefficients, calculated between these values and the physiographic and climatic variables, the mean and minimum values of the daily minimum extreme flows were significantly better correlated with main slope (positive correlation) and agricultural areas (negative correlation) during the two seasons (Table 4). There were also positively correlated with wetland areas, in spring only. In fall, this factor was correlated only with the minimum value of flows. Forest areas were positively correlated with the mean value of flows in spring. Maximum values were not significantly correlated with any physiographic factor during the two seasons. Finally, no climatic factor was significantly correlated with daily minimum extreme flows during the two seasons. 
12
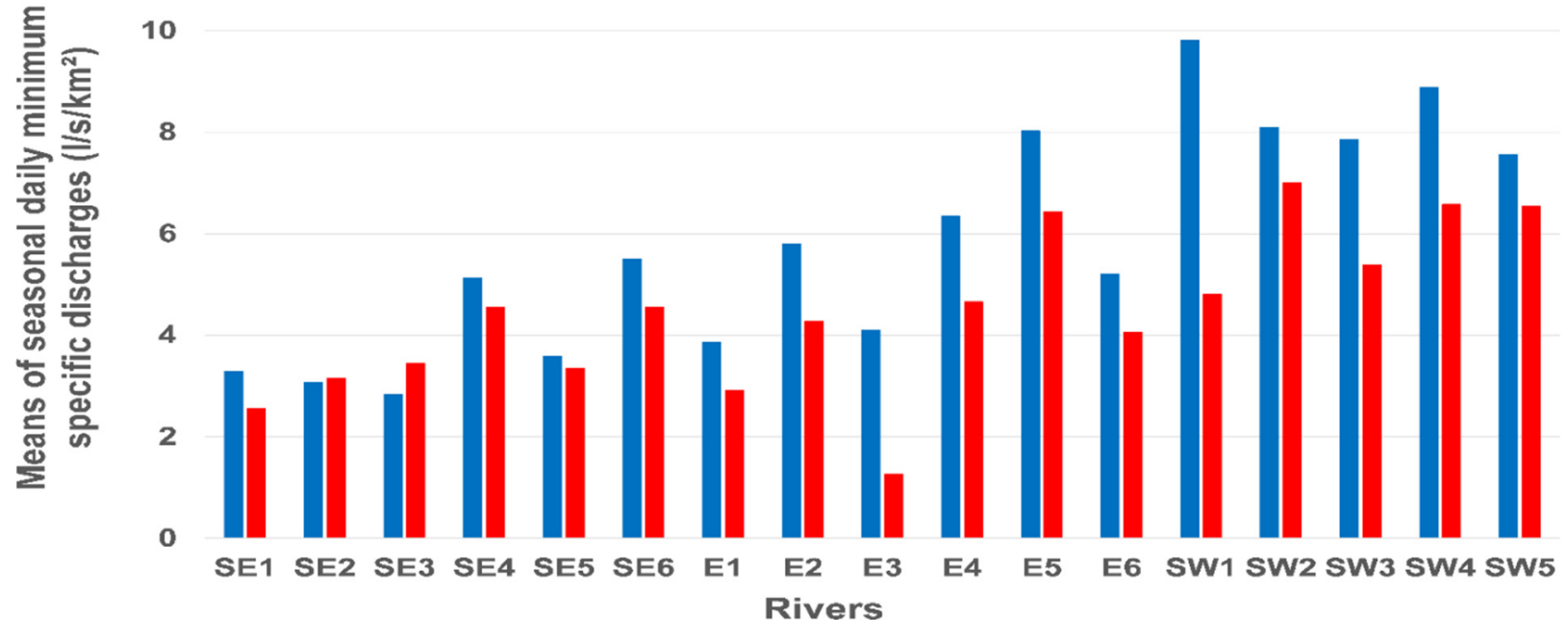

Figure 2. Comparison of average daily minimum extreme flow values in spring (blue bars) and fall (red bars) between 1930 and 2019.

Table 4. Correlation coefficients calculated between physio-climatic variables and magnitude $\left(\mathrm{L} / \mathrm{s} / \mathrm{km}^{2}\right)$ of daily minimum extreme flows in spring and fall between 1930 and 2019.

\begin{tabular}{|c|c|c|c|c|c|c|}
\hline \multirow{2}{*}{ Variables } & \multicolumn{3}{|c|}{ Spring } & \multicolumn{3}{|c|}{ Fall } \\
\hline & Max & Mean & Min & Max & Mean & Min \\
\hline \multicolumn{7}{|c|}{ Physiographic Variables } \\
\hline Drainage density $\left(\mathrm{km} / \mathrm{km}^{2}\right)$ & 0.472 & -0.119 & -0.147 & -0.014 & -0.127 & -0.216 \\
\hline Mean slope (m/km) & -0.030 & $0.671^{* *}$ & $0.550 * *$ & 0.469 & $0.669 * *$ & $0.549^{* *}$ \\
\hline Forests surface area $(\%)$ & 0.002 & $0.484^{* *}$ & 0.388 & 0.150 & 0.463 & 0.381 \\
\hline Agricultural surface area (\%) & 0.081 & $-0.687^{* *}$ & $-0.648^{* *}$ & -0.231 & $-0.580^{* *}$ & $-0.572 * *$ \\
\hline Wetlands surface area $(\%)$ & 0.266 & $0.666^{* *}$ & $0.789 * *$ & 0.447 & 0.426 & $0.528^{* *}$ \\
\hline \multicolumn{7}{|c|}{ Climatic Variables } \\
\hline $\begin{array}{l}\text { Seasonal (spring } / \text { fall) total } \\
\text { rainfall }(\mathrm{mm})\end{array}$ & -0.082 & 0.161 & -0.082 & 0.094 & -0.146 & -0.088 \\
\hline $\begin{array}{l}\text { Seasonal (spring/fall) total } \\
\text { snowfall }(\mathrm{cm})\end{array}$ & 0.253 & -0.271 & -0.407 & -0.052 & -0.399 & -0.370 \\
\hline $\begin{array}{l}\text { Seasonal (spring / fall) total } \\
\text { precipitation }(\mathrm{mm})\end{array}$ & 0.015 & 0.071 & 0.138 & 0.007 & -0.399 & -0.351 \\
\hline $\begin{array}{l}\text { Winter-spring/ summer-fall } \\
\text { total rainfall }(\mathrm{mm})\end{array}$ & -0.098 & 0.099 & 0.254 & 0.109 & -0.087 & -0.160 \\
\hline $\begin{array}{l}\text { Winter-spring/summer-fall } \\
\text { snowfall }(\mathrm{cm})\end{array}$ & 0.058 & -0.139 & -0.282 & -0.052 & -0.399 & -0.369 \\
\hline $\begin{array}{l}\text { Winter-spring/summer-fall } \\
\text { total precipitation }(\mathrm{mm})\end{array}$ & 0.001 & -0.018 & -0.039 & 0.052 & -0.284 & -0.321 \\
\hline $\begin{array}{l}\text { Seasonal (Winter/Spring) } \\
\text { daily mean maximum } \\
\text { temperature }\left({ }^{\circ} \mathrm{C}\right)\end{array}$ & -0.400 & 0.122 & 0.274 & -0.238 & -0.118 & -0.003 \\
\hline $\begin{array}{l}\text { Winter-Spring/Summer-Fall } \\
\text { daily mean maximum } \\
\text { temeperature }\left({ }^{\circ} \mathrm{C}\right)\end{array}$ & -0.423 & 0.056 & 0.252 & -0.084 & 0.088 & 0.121 \\
\hline
\end{tabular}




\subsection{Comparison of Temporal Variability (Long-Term Trend) of Daily Extreme Flows in Spring and Fall}

The results of six trend analysis tests are presented in Table 5 (spring) and Table 6 (fall). Except for the MMKY test, the other five tests yielded consistent results in spring. In total, a statistically significant long-term trend in daily extreme minimum flows was only observed in six rivers ( $35 \%$ of the rivers under analysis): five on the south shore (three to the south and two to the north of $47^{\circ} \mathrm{N}$ ) and only one (L'Assomption) on the north shore, in spring. This trend was also observed in fall. Once again, except for the MMKY, a significant long-term trend in daily minimum extreme flows was observed in eight series: seven on the south shore and only one on the north shore. Unlike in spring, the trend was observed in almost all rivers (four out of six) south of $47^{\circ} \mathrm{N}$. While long-term trends tended to be negative (most $Z$ values were negative) on both shores in spring, except for south-shore rivers located south of $47^{\circ} \mathrm{N}$, they tended to become positive in fall, except for south-shore rivers located north of $47^{\circ} \mathrm{N}$ (Eastern hydroclimatic region). As such, daily minimum extreme flows tended to increase in the southeastern hydroclimatic region in both spring and fall.

Table 5. Results of the various Mann-Kendall tests applied to daily minimum flow series in spring between 1930 and 2019.

\begin{tabular}{|c|c|c|c|c|c|c|c|c|c|c|c|c|}
\hline \multirow[t]{2}{*}{ Rivers } & \multicolumn{2}{|l|}{ MK } & \multicolumn{2}{|c|}{ MMK-PW } & \multicolumn{2}{|c|}{ TFPW } & \multicolumn{2}{|c|}{ MMKY } & \multicolumn{2}{|c|}{ МMКН } & \multicolumn{2}{|c|}{ LTP } \\
\hline & $\mathbf{Z}$ & $\begin{array}{c}p- \\
\text { Value }\end{array}$ & $\mathbf{Z}$ & $\begin{array}{c}p- \\
\text { Value }\end{array}$ & $\mathbf{Z}$ & $\begin{array}{c}p- \\
\text { Value }\end{array}$ & $\mathbf{Z}$ & $\begin{array}{c}p- \\
\text { Value }\end{array}$ & $\mathbf{Z}$ & $\begin{array}{c}p- \\
\text { Value }\end{array}$ & $\mathbf{Z}$ & $\begin{array}{c}p- \\
\text { Value }\end{array}$ \\
\hline \multicolumn{13}{|c|}{ Southeastern Hydroclimatic Region } \\
\hline Chateaugay & 1.115 & 0.265 & 1.393 & 0.164 & 1.279 & 0.201 & $2.621 * *$ & 0.009 & 1.102 & 0.271 & 1.190 & 0.234 \\
\hline Eaton & -0.317 & 0.751 & -0.594 & 0.553 & -0.565 & 0.572 & -0.966 & 0.334 & -0.351 & 0.726 & -0.441 & 0.667 \\
\hline $\begin{array}{l}\text { Nicolet } \\
\text { SW }\end{array}$ & 2.266 & 0.023 & 1.488 & 0.116 & 1.386 & 0.666 & $2.884 * *$ & 0.004 & $1.708^{* *}$ & 0.088 & $1.700 *$ & 0.089 \\
\hline Etchemin & 1.460 & 0.144 & 1.488 & 0.137 & 1.669 & 0.095 & $2.791 * *$ & 0.005 & 1.364 & 0.172 & 1.110 & 0.267 \\
\hline Beaurivage & 5.309 & 0.000 & 5.142 & 0.000 & 5.589 & 0.000 & $9.559 * *$ & 0.000 & $4.723 * *$ & 0.000 & $4.737 * *$ & 0.000 \\
\hline Du Sud & 0.220 & 0.826 & 0.620 & 0.534 & 0.641 & 0.521 & 0.502 & 0.615 & 0.179 & 0.858 & 0.183 & 0.855 \\
\hline \multicolumn{13}{|c|}{ Eastern Hydroclimatic Region } \\
\hline Ouelle & $-4.392 * *$ & 0.000 & $-3.81 * *$ & 0.000 & $-4.4 * *$ & 0.000 & $-11.9 * *$ & 0.000 & $-4.15 * *$ & 0.000 & $-4.32 * *$ & 0.000 \\
\hline Du Loup & 0.540 & 0.589 & 1.024 & 0.306 & 1.152 & 0.249 & 0.992 & 0.321 & 0.523 & 0.601 & 0.284 & 0.777 \\
\hline $\begin{array}{c}\text { Trois- } \\
\text { Pistoles }\end{array}$ & $-2.18^{* *}$ & 0.029 & $-1.92 *$ & 0.055 & $-2.0 * *$ & 0.048 & $-3.74 * *$ & 0.000 & $-2.31 * *$ & 0.021 & $-2.10 * *$ & 0.037 \\
\hline Rimouski & -1.056 & 0.291 & -1.123 & 0.261 & -1.194 & 0.232 & -1.319 & 0.187 & -1.050 & 0.294 & -1.130 & 0.262 \\
\hline Matane & $-2.27 * *$ & 0.023 & $-2.69 * *$ & 0.007 & $-2.7 * *$ & 0.006 & $-3.84 * *$ & 0.000 & $-2.46^{* *}$ & 0.014 & $-2.92 * *$ & 0.004 \\
\hline Blanche & -0.384 & 0.701 & -0.049 & 0.961 & -0.118 & 0.906 & -0.596 & 0.551 & -0.450 & 0.653 & -0.219 & 0.830 \\
\hline \multicolumn{13}{|c|}{ Southwestern Hydroclimatic Region } \\
\hline $\begin{array}{l}\text { Petite } \\
\text { Nation }\end{array}$ & 1.063 & 0.288 & 1.414 & 0.157 & 1.265 & 0.206 & 2.401 & 0.016 & 1.063 & 0.288 & 1.257 & 0.209 \\
\hline Du Nord & -0.393 & 0.694 & -0.458 & 0.647 & -0.407 & 0.684 & -0.876 & 0.381 & -0.761 & 0.447 & -0.612 & 0.548 \\
\hline L'Assomption & -1.506 & 0.132 & -1.449 & 0.147 & -1.286 & 0.198 & $-5.57 * *$ & 0.000 & -1.726 * & 0.084 & $-2.97 * *$ & 0.003 \\
\hline Matawin & -1.506 & 0.132 & -0.157 & 0.876 & -0.157 & 0.876 & -0.231 & 0.817 & -0.121 & 0.904 & -0.091 & 0.931 \\
\hline Vermillon & 0.821 & 0.417 & 1.258 & 0.208 & 1.045 & 0.296 & 3.513 & 0.000 & 0.920 & 0.358 & 1.062 & 0.288 \\
\hline
\end{tabular}

${ }^{* *}=$ significant values over the $5 \%$ threshold are shown in red/blue bold; ${ }^{*}=$ significant values over the $10 \%$ threshold are shown in red/blue bold. Blue = negative trends; red = positive trends. 
Table 6. Results of the various Mann-Kendall tests applied to daily minimum flow series in fall between 1930 and 2019.

\begin{tabular}{|c|c|c|c|c|c|c|c|c|c|c|c|c|}
\hline \multirow[t]{2}{*}{ Rivers } & \multicolumn{2}{|c|}{ MK } & \multicolumn{2}{|c|}{ MMK-PW } & \multicolumn{2}{|c|}{ TFPW } & \multicolumn{2}{|c|}{ MMKY } & \multicolumn{2}{|c|}{ ММКН } & \multicolumn{2}{|c|}{ LTP } \\
\hline & $\mathbf{Z}$ & $\begin{array}{c}p- \\
\text { Value }\end{array}$ & $\mathbf{Z}$ & $\begin{array}{c}p- \\
\text { Value }\end{array}$ & $\mathbf{Z}$ & $\begin{array}{c}p- \\
\text { Value }\end{array}$ & $\mathrm{Z}$ & $\begin{array}{c}p- \\
\text { Value }\end{array}$ & $\mathbf{Z}$ & $\begin{array}{c}p- \\
\text { Value }\end{array}$ & $\mathbf{Z}$ & $\begin{array}{c}p- \\
\text { Value }\end{array}$ \\
\hline \multicolumn{13}{|c|}{ Southeastern Hydroclimatic Region } \\
\hline Chateaugay & 1.362 & 0.173 & 0.173 & 3.399 & $3.694 * *$ & 0.000 & $8.468 * *$ & 0.000 & $3.831 * *$ & 0.000 & $2.947 * *$ & 0.003 \\
\hline Eaton & 1.100 & 0.217 & 0.932 & 0.333 & 1.067 & 0.286 & $1.968 * *$ & 0.049 & 1.100 & 0.271 & 0.722 & 0.470 \\
\hline $\begin{array}{l}\text { Nicolet } \\
\text { SW }\end{array}$ & $3.275 * *$ & 0.001 & $2.671 * *$ & 0.008 & $3.254 * *$ & 0.001 & $5.888 * *$ & 0.000 & $3.744^{* *}$ & 0.000 & $2.085 * *$ & 0.037 \\
\hline Etchemin & 2.754 ** & 0.006 & $2.112 * *$ & 0.035 & 2.676 ** & 0.007 & $4.545 * *$ & 0.000 & $1.992 * *$ & 0.046 & 1.225 & 0.221 \\
\hline Beaurivage & $3.820 * *$ & 0.000 & $2.662 * *$ & 0.008 & $3.600 * *$ & 0.000 & $6.502 * *$ & 0.000 & $3.574^{* *}$ & 0.000 & $1.948 *$ & 0.051 \\
\hline Du Sud & $1.99 * *$ & 0.044 & 1.063 & 0.288 & 1.395 & 0.163 & $2.232 * *$ & 0.026 & 0.998 & 0.668 & 0.668 & 0.504 \\
\hline \multicolumn{13}{|c|}{ Eastern Hydroclimatic Region } \\
\hline Ouelle & -0.472 & 0.637 & -0.308 & 0.758 & -0.359 & 0.719 & -0.807 & 0.419 & -0.454 & 0.650 & -0.244 & 0.810 \\
\hline Du Loup & -0.991 & 0.322 & -0.836 & 0.403 & -0.799 & 0.424 & $-2.036^{* *}$ & 0.042 & -0.991 & 0.318 & -0.726 & 0.471 \\
\hline $\begin{array}{c}\text { Trois- } \\
\text { Pistoles }\end{array}$ & $-2.141 * *$ & 0.032 & $-1.921 *$ & 0.055 & $-1.957 *$ & 0.050 & $-4.26^{* *}$ & 0.000 & $-2.14 * *$ & 0.032 & -1.618 & 0.107 \\
\hline Rimouski & -0.493 & 0.622 & -0.256 & 0.798 & -0.314 & 0.754 & -0.899 & 0.369 & -0.505 & 0.614 & -0.293 & 0.773 \\
\hline Matane & $-2.265 * *$ & 0.024 & $-1.770 *$ & 0.077 & $-2.05 * *$ & 0.040 & $-6.46 * *$ & 0.000 & $-2.27^{* *}$ & 0.024 & $-1.687^{*}$ & 0.093 \\
\hline Blanche & 0.752 & 0.452 & 0.537 & 0.591 & 0.583 & 0.560 & 1.504 & 0.133 & 0.752 & 0.452 & 0.498 & 0.620 \\
\hline \multicolumn{13}{|c|}{ Southwestern Hydroclimatic Region } \\
\hline $\begin{array}{l}\text { Petite } \\
\text { Nation }\end{array}$ & 1.362 & 0.173 & 1.503 & 0.133 & 1.532 & 0.125 & $2.995 * *$ & 0.003 & 1.046 & 0.163 & 1.531 & 0.126 \\
\hline Du Nord & 0.872 & 0.383 & 0.968 & 0.333 & 0.792 & 0.428 & $2.881 * *$ & 0.004 & 1.156 & 0.248 & $1.860 *$ & 0.063 \\
\hline L'Assomption & 0.911 & 0.362 & 0.918 & 0.358 & 0.782 & 0.434 & $2.455 * *$ & 0.014 & 0.869 & 0.385 & 1.085 & 0.278 \\
\hline Matawin & 0.358 & 0.720 & 0.247 & 0.805 & 0.194 & 0.847 & 1.022 & 0.307 & 0.444 & 0.657 & 0.496 & 0.620 \\
\hline Vermillon & 0.092 & 0.927 & 0.256 & 0.798 & 0.249 & 0.804 & 0.200 & 0.841 & 0.079 & 0.930 & 0.094 & 0z.925 \\
\hline
\end{tabular}

These long-term trends were partially confirmed by the three tests to detect shifts in means, the results of which were nearly consistent. In spring, these three tests detected breaks in the mean of flow of four rivers, three of which were located north of $47^{\circ} \mathrm{N}$. However, the dates of these shifts were not synchronous, occurring in different decades (Table 7). In fall, breaks in mean were detected in seven rivers, five of which were located south of $47^{\circ} \mathrm{N}$ (Table 8). Surprisingly, these breaks in mean were nearly synchronous, and occurred during the 1960s (Figure 3) in these five rivers, which clearly indicates that their consistency is regional. In the two rivers north of this parallel, these shifts occurred later.

In the 1980s and 1990s, none of the three tests detected shifts in the mean of daily minimum flows on the north shore in either season, which suggests that there were also no shifts in the mean of daily minimum extreme flows in the rivers on the north shore in either season.

Rivers in the southeastern hydroclimatic region were further analyzed in the fall to determine if a shift in mean occurred subsequent to the break in the 1960s. The MK tests, and the tests to detect changes in shifts in mean, were repeated, and revealed no other statistically significant changes in either the long-term trend or the means of the hydrological series after the 1960s. Consequently, the moisture of the 2010s did not cause a significant increase in daily minimum extreme flows during the two transitional seasons in southern Quebec. However, Figure 3 shows that, even in the most agricultural south 
shore watersheds south of $47^{\circ} \mathrm{N}$, minimum flows decreased over the course of the decade, despite a substantial increase in flows in the 1960s.

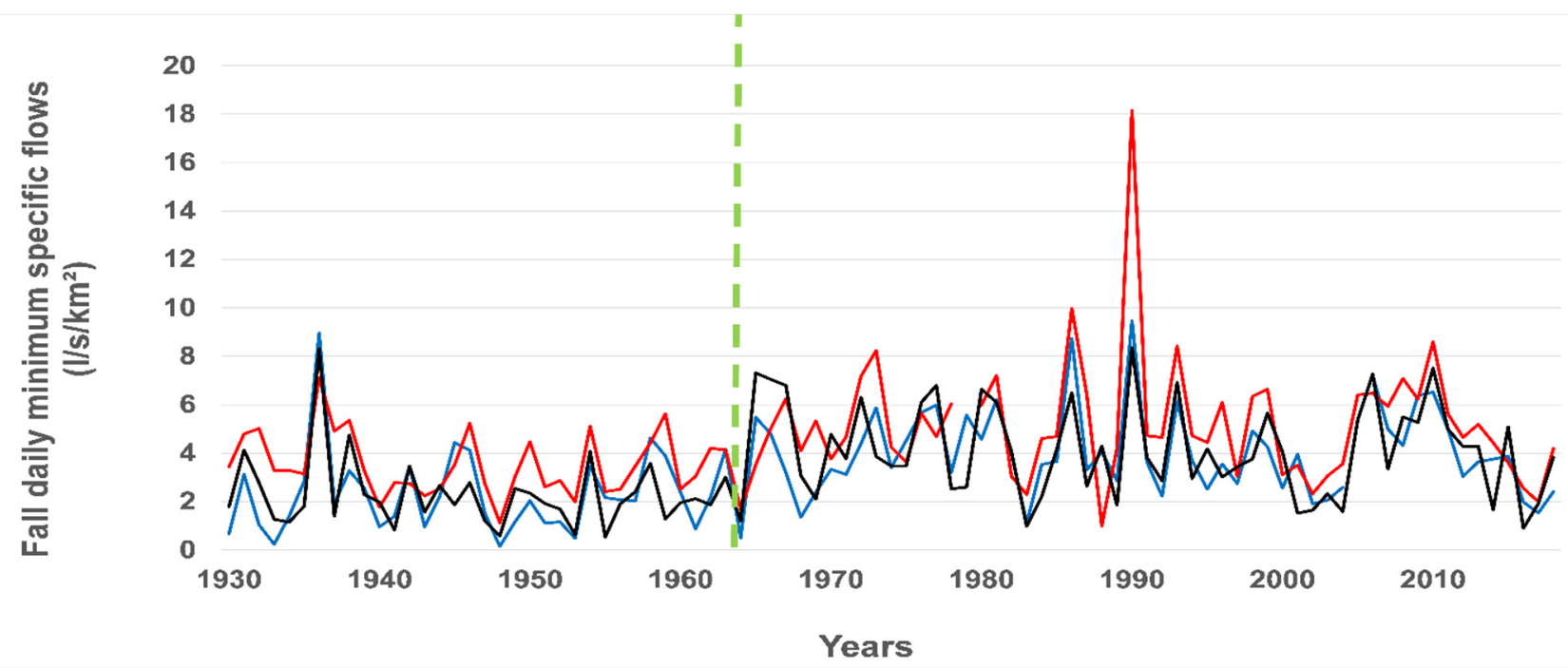

Figure 3. Example of the interannual variability in the daily minimum extreme flows in fall of three rivers in the southeast hydroclimatic region on the south shore. The dashed vertical green line indicates the year of shift in mean of the hydrological series. Beaurivage River (blue curve); Etchemin River (red curve); Nicolet SW River (black curve). The shift in mean of flows occurred almost the same year for all three rivers.

Table 7. Results of the various Pettitt and Lombard tests applied to daily minimum flow series in spring between 1930 and 2019.

\begin{tabular}{|c|c|c|c|c|c|c|c|c|}
\hline & \multicolumn{3}{|c|}{ Pettitt Test } & \multicolumn{3}{|c|}{ Modified Pettitt Test } & \multicolumn{2}{|c|}{ Lombard Test } \\
\hline & $\mathbf{K}$ & $p$-Value & $\mathbf{T}$ & K & $p$-Value & $\mathrm{T}$ & $S_{n}$ & T1-T2 \\
\hline \multicolumn{9}{|c|}{ Southeastern Hydroclimatic Region } \\
\hline Chateaugay & 545 & 0.178 & - & 580 & 0.129 & - & 0.017 & - \\
\hline Eaton & 282 & 1.001 & - & 317 & 0.834 & - & 0.003 & - \\
\hline Nicolet SW & 492 & 0.247 & - & 546 & 0.177 & - & 0.021 & - \\
\hline Etchemin & 647 & 0.066 & - & 591 & 0.117 & - & 0.029 & - \\
\hline Beaurivage & $1298 * *$ & 0.000 & 1968 & $1219 * *$ & 0.000 & 1968 & $0.258 * *$ & $1967-68$ \\
\hline Du Sud & 376 & 0.633 & - & 376 & 0.633 & - & 0.002 & - \\
\hline \multicolumn{9}{|c|}{ Eastern Hydroclimatic Region } \\
\hline Ouelle & $984 * *$ & 0.001 & 1986 & $889 * *$ & 0.003 & 1986 & $0.176 * *$ & 1930-99 \\
\hline Du Loup & 530 & 0.203 & - & 536 & 0.193 & - & 0.006 & - \\
\hline Trois-Pistoles & 593 & 0.114 & - & 606 & 0.101 & - & $0.0489 * *$ & $1951-52$ \\
\hline Rimouski & 363 & 0.684 & - & 341 & 0.776 & - & 0.010 & - \\
\hline Matane & $765 * *$ & 0.017 & 1963 & $856 * *$ & 0.005 & 1963 & $0.061 * *$ & $1961-62$ \\
\hline Blanche & 389 & 0.488 & - & 297 & 0.879 & - & 0.003 & - \\
\hline
\end{tabular}


Table 7. Cont.

\begin{tabular}{|c|c|c|c|c|c|c|c|c|}
\hline & \multicolumn{3}{|c|}{ Pettitt Test } & \multicolumn{3}{|c|}{ Modified Pettitt Test } & \multicolumn{2}{|c|}{ Lombard Test } \\
\hline & $\mathbf{K}$ & $p$-Value & $\mathbf{T}$ & $\mathrm{K}$ & $p$-Value & $\mathbf{T}$ & $S_{n}$ & T1-T2 \\
\hline \multicolumn{9}{|c|}{ Southwestern Hydroclimatic Region } \\
\hline Petite Nation & 525 & 0.212 & - & 608 & 0.099 & - & 0.014 & - \\
\hline Du Nord & 269 & 1.088 & - & 238 & 1.242 & - & 0.005 & - \\
\hline L'Assomption & 378 & 0.625 & - & 415 & 0.492 & - & 0.018 & - \\
\hline Matawin & 482 & 0.247 & - & 502 & 0.207 & - & 0.002 & - \\
\hline Vermillon & 387 & 0.591 & - & 497 & 0.268 & - & 0.008 & - \\
\hline
\end{tabular}

${ }^{* *}=$ significant values at the $5 \%$ threshold are shown in red bold; $\mathrm{T}=$ year of the shift mean; $\mathrm{T} 1-\mathrm{T} 2=$ year before (T1) and after (T2) of shift mean; $\mathrm{K}=$ calculated values of Pettitt test; $\mathrm{Sn}=$ calculated values of Lombard test. Blue = drop in the means after the shift; Red bold= Rise in the means after the shift.

\section{Discussion}

Analysis of the spatial variability of minimum extreme flows in spring and fall revealed a clear difference between the rivers on the south shore of the St. Lawrence River (south of $47^{\circ} \mathrm{N}$ ) and those on the north shore. The means of these flows tended to be greater on the north shore $\left(>5 \mathrm{~L} / \mathrm{s} / \mathrm{km}^{2}\right)$ than on the south shore $\left(<5 \mathrm{~L} / \mathrm{s} / \mathrm{km}^{2}\right)$. The correlation analysis between these flows and physiographic factors revealed that two main factors influence the spatial variability of flows: agricultural areas and mean slope, which, respectively, were negatively and positively correlated. In the spring, these flows are also influenced by wetland areas (positive correlation). The south shore watersheds, located south of $47^{\circ} \mathrm{N}$, tend to have relatively large agricultural areas $(>20 \%)$, but very small wetlands $(<4 \%)$. Conversely, the watersheds on the north shore have larger wetlands $(>8 \%)$ but very small agricultural areas $(<5 \%)$. The impacts of land use on river flows are well documented in the scientific literature, even in Canada $[53,54]$. With respect to agriculture, previous research in Quebec has shown that agricultural land use reduces minimum flows due to soil sealing, which limits infiltration into aquifers, the main source of streamflow during low-water periods in winter, summer, and fall [55-58].

Table 8. Results of the two Pettitt and Lombard tests applied to the daily minimum flow series in fall between 1930 and 2019.

\begin{tabular}{|c|c|c|c|c|c|c|c|c|}
\hline & \multicolumn{3}{|c|}{ Pettitt Test } & \multicolumn{3}{|c|}{ Modified Pettitt Test } & \multicolumn{2}{|c|}{ Lombard Test } \\
\hline & $\mathbf{K}$ & $p$-Value & $\mathbf{T}$ & $\mathbf{K}$ & $p$-Value & $\mathbf{T}$ & Sn & T1-T2 \\
\hline \multicolumn{9}{|c|}{ Southeastern Hydroclimatic Region } \\
\hline Chateaugay & $1023 * *$ & 0.000 & 1964 & $930 * *$ & 0.001 & 1962 & $0.156 * *$ & 1961-62 \\
\hline Eaton & 572 & 0.105 & - & 510 & 0.192 & - & 0.010 & - \\
\hline Nicolet SW & $1137 * *$ & 0.000 & 1965 & $948 * *$ & 0.001 & 1964 & $0.107 * *$ & 1963-64 \\
\hline Etchemin & $966 * *$ & 0.001 & 1965 & $784 * *$ & 0.009 & 1965 & $0.075 * *$ & 1964-65 \\
\hline Beaurivage & $1114 * *$ & 0.000 & 1964 & $892 * *$ & 0.002 & 1964 & $0.121 * *$ & 1963-64 \\
\hline Du Sud & $814 * *$ & 0.044 & 1970 & $752 * *$ & 0.011 & 1968 & $0.060 *$ & $1966-68$ \\
\hline \multicolumn{9}{|c|}{ Eastern Hydroclimatic Region } \\
\hline Ouelle & 431 & 0.397 & - & 373 & 0.596 & - & 0.003 & - \\
\hline Du Loup & 456 & 0.327 & - & 430 & 0.400 & - & 0.013 & - \\
\hline Trois-Pistoles & $656 *$ & 0.080 & 1988 & $660 *$ & 0.051 & 1988 & $0.049 * *$ & 1992-93 \\
\hline Rimouski & 502 & 0.240 & - & 488 & 0.270 & - & 0.004 & - \\
\hline Matane & 619 * & 0.080 & 1976 & $556 *$ & 0.148 & - & $0.055 * *$ & $1982-83$ \\
\hline Blanche & 308 & 0.800 & - & 302 & 0.829 & - & 0.004 & - \\
\hline
\end{tabular}


Table 8. Cont.

\begin{tabular}{|c|c|c|c|c|c|c|c|c|}
\hline & \multicolumn{3}{|c|}{ Pettitt Test } & \multicolumn{3}{|c|}{ Modified Pettitt Test } & \multicolumn{2}{|c|}{ Lombard Test } \\
\hline & $\mathbf{K}$ & $p$-Value & $\mathbf{T}$ & $\mathbf{K}$ & $p$-Value & $\mathbf{T}$ & Sn & T1-T2 \\
\hline \multicolumn{9}{|c|}{ Southwestern Hydroclimatic Region } \\
\hline Petite Nation & 425 & 0.415 & - & 469 & 0.295 & - & 0.010 & - \\
\hline Du Nord & 298 & 0.923 & - & 385 & 0.550 & - & 0.004 & - \\
\hline L'Assomption & 442 & 0.386 & - & 526 & 0.195 & - & 0.009 & - \\
\hline Matawin & 314 & 0.798 & - & 409 & 0.420 & - & 0.002 & - \\
\hline Vermillon & 376 & 0.632 & - & 432 & 0.416 & - & 0.002 & - \\
\hline
\end{tabular}

** $($ red/blue bold $)=$ significant values over the $5 \%$ threshold $; *($ red bold $/$ blue bold $)=$ significant value over the $10 \%$ threshold. $\mathrm{T}=$ year of the shift in mean; T1-T2 = year before (T1) and after (T2) the shift in mean; $\mathrm{K}=$ calculated values of Pettitt test; $\mathrm{Sn}=$ calculated values of Lombard test. Blue $=$ drop in the means after the shift; red = rise in the means after the shift.

This soil sealing also accelerates spring recession in agricultural watersheds [51], which explains the low minimum extreme flows observed in spring and fall in the most agricultural watersheds on the south shore. As for the impacts of wetlands on these minimum extreme flows, there is still no research on the topic in Quebec, and very little internationally. In their summary on the hydrological impacts of wetlands, Bullock and Acreman [52] highlighted the complexity of the relationship between wetlands, aquifers, and minimum flows. This complexity led to divergent results: some studies showed that minimum flows decreased in wetlands, while others showed an increase. In Quebec, it is quite clear that wetlands cause an increase in extreme minimum flows in spring. In this season, minimum flows are mainly associated with recession caused by snowmelt. Thus, wetlands slow this recession, as minimum flows are maintained at higher values than those observed in agricultural watersheds on the south shore (the "sponge effect"), where discharge from snowmelt and/or rainwater is much faster. A recent study showed that spring freshets caused by snowmelt don't last as long in agricultural watersheds on the south shore than in those on the north shore, as runoff is more significant and faster in the first watersheds (Assani, 2021; unpublished work). In fall, minimum flows are mainly influenced by groundwater. In this season, precipitation mainly falls as rain. But, unlike freshets and rain-induced flood flows, the "sponge effect" of wetlands on the daily minimum extreme flows (July to November) acts tacitly, and results in a slower decrease in flows during low-flows events, probably due to the poor connectivity between these wetlands and aquifers [59]. This may partly explain the significant positive correlation observed between wetlands and the lowest value of the daily minimum extreme flows in fall.

In addition to agricultural areas and wetlands, there was a significant positive correlation between the mean slope and daily minimum extreme flows in both spring and fall. This correlation is explained by the fact that this physiographic factor, in the very agricultural south shore watersheds, is generally less steep than on the north shore, because a large share of the south shore watersheds' surface area lies in the St. Lawrence Lowlands, a geological formation with a relatively flat topography. By contrast, nearly all the north shore watersheds are located on the Canadian Shield, which has a relatively irregular topography (consisting of hills and valleys). Thus, this correlation between these two variables does not express a direct causal link, but a covariation due to agricultural areas of the watersheds.

Analysis of the temporal variability of daily minimum extreme flows also revealed a marked difference between south-shore and north-shore rivers south of $47^{\circ} \mathrm{N}$, particularly in fall. In fact, at that time of year, south-shore rivers located south of this parallel tended to see a significant increase in daily minimum extreme flows, while no significant changes were observed in the north-shore rivers. This increase in flows happened in near-perfect synchronicity for most rivers during the 1960s. This increase can be explained by two factors: 
1. The modernization of agricultural practices in southern Quebec since 1950, which led to a significant reduction of cultivated land. Cultivated land was left uncropped or reforested, the amount of which nearly tripled in area between 1950 and 1981 [60]. From a hydrological perspective, this type of land use change would promote the infiltration of water into the soil, increasing fall minimum extreme flows supplied primarily by groundwater. In addition to reduction in the cultivated area, the type of the crop has also changed. As a result, forage crop acreage was reduced by over half to make room for oats, corn, and soybeans, particularly between 1950 and 2011 [60]. This change in crop type could change the conditions for runoff and infiltration of snowmelt and rainwater to varying degrees. The increase in minimum flows resulting from changes in agricultural practices has been observed in many watersheds in agricultural regions of the United States [27].

2. Increased rainfall in summer and fall in the northeastern part of North America. Several studies have noted a significant increase in rainfall, particularly in fall, in the northeastern part of North America north of $44^{\circ} \mathrm{N}[13,17,22,25]$, and on the south shore of Quebec south of $47^{\circ} \mathrm{N}[61,62]$. This increase occurred during the 1960s and early 1970s.

The reduction of cultivated land in favor of fallow land, in addition to the increase in precipitation, may therefore explain the increase in daily minimum extreme flows observed in fall in the southeastern hydroclimatic region (south of $47^{\circ} \mathrm{N}$ ) - the most agricultural region in Quebec. This increase was also observed in rivers in the northeastern part of the United States $[29,32]$.

The predominant fact to emerge from our analysis of temporal variability in spring was the tendency of daily minimum extreme flows to decrease on the south shore north of $47^{\circ} \mathrm{N}$ (Eastern hydroclimatic region), in contrast with the region just south of this parallel. This decrease may be linked to snowfall in winter [28,36], although this decrease in snow cover was more extensive on the north shore than on the south shore [36]. However, no significant changes in the means of flows were observed on the north shore. It follows that the decrease in amount of snow does not seem to affect the spring daily minimum extreme flows. The impacts of this decrease in the amount of snow would probably be mitigated by wetlands in the region. This hypothesis deserves to be explored.

\section{Conclusions}

Analysis of the spatial and temporal variability of daily minimum extreme flows during the transitional seasons (spring and fall) between 1930 and 2019 revealed a marked difference between rivers on the north and south shores of the St. Lawrence River south of $47^{\circ} \mathrm{N}$. In terms of spatial variability, rivers on the south shore have lower daily minimum extreme flows than those on the north shore. This difference was mainly due to agricultural areas. South shore watersheds have a larger agricultural area than those on the north shore. Agriculture reduces water infiltration in fall and accelerates runoff in spring.

With respect to temporal variability, the same difference was observed between the north and south shores in fall. Daily minimum extreme flows have increased significantly in south-shore rivers since the 1960s. This increase is due to a reduction in cultivated land following the modernization of agricultural practices in Quebec since the 1960, as well as an increase in rainfall in the region since the 1970s. Decreased snowfall in Quebec does not yet appear to significantly affect the long-term trend of daily minimum extreme flows in spring, despite the observation of a downward trend north of $47^{\circ} \mathrm{N}$ on both the south and north shores. In fall, the overall increase in temperature in summer and early fall did not lead to a decrease in fall daily minimum extreme flows, as the increase in rainfall offsets the increase in evapotranspiration resulting from this summer-fall warming.

According to climate models, warmer temperatures in Quebec will result in a significant decrease in the amount of snow in spring, which will in turn reduce runoff and infiltration. This will result in a significant decrease in the magnitude of spring freshets and low-water levels. In fall, these climate models predict a significant increase in temperature 
that will be accompanied by more intense rainfall. This scenario will result in a continuous increase in low-water flows. There will therefore be a continuous decrease in low-water flows in spring but a continuous increase in low-water flows in fall. It is this trend that will be followed in the future.

Author Contributions: Conceptualization, A.A.A.; methodology, A.A.A. and A.Z.; formal analysis, A.A.A. and A.Z.; investigation, A.A.A., A.Z., A.R. and C.K.; writing-original draft preparation, A.A.A., A.Z., A.R. and C.K.; writing—review and editing, A.A.A., A.Z., A.R. and C.K.; funding acquisition, A.A.A. All authors have read and agreed to the published version of the manuscript.

Funding: This research was funded by the Natural Sciences and Engineering Research Council of Canada (NSERC), grant number "261274/2019".

Data Availability Statement: The data presented in this study are available on request from the corresponding author.

Conflicts of Interest: The authors declare no conflict of interest.

\section{References}

1. Danco, J.F.; DEAngilils, A.; Raney, B.K.; Broccoli, A.J. Effects of a warming climate on daily snowfall events in the Northern Hemisphere. J. Clim. 2016, 29, 6295-6318. [CrossRef]

2. Kapnick, S.B.; Delworth, T.L. Controls of global snow under a changed climate. J. Clim. 2013, 26, 5537-5562. [CrossRef]

3. Krasting, J.P.; Broccoli, A.J.; Dixon, K.W.; Lanzante, J.R. Future changes in Northern Hemisphere snowfall. J. Clim. 2013, 26, 7813-7828. [CrossRef]

4. O'Gorman, P. Contrasting responses of mean and extreme snowfall to climate change. Nature 2014, 512, 416-418. [CrossRef] [PubMed]

5. Janoski, T.P.; Broccoli, A.J.; Kapnick, S.B.; Johnson, N. Effects of climate change on wind-driven heavy-snowfall events over Eastern North America. J. Clim. 2018, 31, 9037-9054. [CrossRef]

6. Ingram, W. Extreme precipitation: Increases all round. Nat. Clim. Chang. 2016, 6, 443-444. [CrossRef]

7. Tabari, H. Climate change impact on flood and extreme precipitation increase with water availibility. Nat. Sci. Rep. 2020, 10, 13768. [CrossRef] [PubMed]

8. Marx, A.; Kumar, R.; Thober, S.; Zink, M.; Wanders, N.; Wood, E.F.; Pan, M.; Sheffield, J.; Samaniogo, L. Climate change alters low flows in Europe under a 1.5, 2, and 3 degree global warming. Hydrol. Earth. Syst. Sci. Discuss. 2017, 1-24. [CrossRef]

9. Assefa, K.; Moges, M.A. Low Flow Trends and Frequency Analysis in the Blue Nile Basin, Ethiopia. J. Water Res. Protec. 2018, 10, 182-203. [CrossRef]

10. Blum, A.G.; Archfield, S.A.; Hirsch, R.M.; Vogel, R.M.; Kiang, J.E.; Dudley, W. Updating estimates of low-streamflow statistics to account for possible trends. Hydrol. Sci. J. 2019, 64, 1404-1414. [CrossRef]

11. Ehsanzadeh, E.; Adamowski, K. Trends in timing of low stream flows in Canada: Impact of autocorrelation and long-term persistence. Hydrol. Process. 2010, 24, 970-980. [CrossRef]

12. Déry, S.J.; Hernández-Henríquez, M.A.; Owens, P.N.; Parkes, M.W.; Petticrew, E.L. A century of hydrological variability and trends in the Fraser Rive basin. Environ. Res. Lett. 2012, 7, 024019. [CrossRef]

13. Dudley, R.W.; Hirsh, R.M.; Archfiled, S.A.; Blum, A.G.; Renard, B. Low trends at human-impacted and reference basins in the United States. J. Hydrol. 2020, 580, 124254. [CrossRef]

14. Gain, A.K.; Immerzeel, W.W.; Sperna-Weiland, F.C.; Bierkens, M.F.P. Impact of climate change on the stream flow of lower Brahmaputra: Trends in high and low flows based on discharge-weighted ensemble modelling. Hydrol. Earth Syst. Sci. 2011, 8, 365-390. [CrossRef]

15. Hammond, J.C.; Fleming, B.J. Evaluating low flow patterns, drivers and trends in the Delaware river basin. J. Hydrol. 2021, 598, 126246. [CrossRef]

16. Hannaford, J. Climate-driven changes in UK river flows: A review of the evidence. Progr. Phys. Geogr. 2015, 39, 29-48. [CrossRef]

17. Hodgkins, G.A.; Dudley, R.W. Historical summer base flow and stromflow trends for New England rivers. Water Resourc. Res. 2011, 47, W07528. [CrossRef]

18. Khaliq, M.N.; Ouarda, T.B.M.J.; Gachon, P. Identification of temporal trends in annual and seasonal low flows occuring in Canadian rivers: The effect of short- and long-term persistence. J. Hydrol. 2009, 369, 183-197. [CrossRef]

19. Khaliq, M.N.; Ouarda, T.B.M.J.; Gachon, P.; Sushama, L. Temporal evolution of low-flow regimes in Canadian rivers. Water Resourc. Res. 2008, 44, W08436. [CrossRef]

20. Kay, A.L.; Bell, V.A.; Guillod, B.P.; Jones, R.G. Rudd, A.C. National-scale analysis of low flow frequency: Historical trends and potential future changes. Clim. Chang. 2018, 147, 585-599. [CrossRef]

21. Kormos, P.R.; Luce, C.H.; Wenger, S.J.; Berghuijs, W.R. Trends and sensitivities of low streamflow extremes to discharge timing and magnitude in Pacific Northwest mountain streams. Water Resour. Res. 2016, 52, 4990-5007. [CrossRef] 
22. Sadri, S.; Kam, J.; Sheffield, J. Nonstationarity of low flows and their timing in the eastern United States. Hydrol. Earth Syst. Sci. 2016, 20, 633-649. [CrossRef]

23. Sahoo, B.B.; Jha, R. Assessment of low flow trends and change point detection in Mahanadi River basin, India. Sustain. Water Resour. Manag. 2020, 6, 81. [CrossRef]

24. Sawaske, S.P.; Freyberg, D.L. An analysis of trends in baseflow recession and low-flows in rain-dominated coastal streams of the pacific coast. J. Hydrol. 2014, 519, 599-610. [CrossRef]

25. Small, D.; Islam, S.; Vogel, R.M. Trends in precipitation and streamflow in the eastern U.S.: Paradox or perception? Geophys. Res. Lett. 2006, 13, L03403. [CrossRef]

26. Vlach, V.; Ledvinka, O.; Matouskova, M. Changing low flow and streamflow drought seasonality in Central European headwaters. Water 2020, 12, 3575. [CrossRef]

27. Zhang, Y.-K.; Schilling, K.E. Increasing streamflow and base flow in Mississippi River since the 1940s: Effect of land use change. J. Hydrol. 2006, 324, 412-422. [CrossRef]

28. Brown, R.D. Analysis of snow cover variability and change in Québec, 1948-2005. Hydrol. Process. 2010, 24, 1929-1954. [CrossRef]

29. Fortin, G.; Hétu, B. Estimating winter trends in climatic variables in the Chic-Chocs Mountains, Canada (1970-2009). Int. J. Climatol. 2013, 34, 3078-3088. [CrossRef]

30. Yagouti, A.; Boulet, G.; Vincent, L.; Vescovi, L.; Mekis, E. Observed changes in daily temperature and precipitation indices for Southern Québec, 1960-2005. Atmos. Ocean. 2008, 46, 243-256. [CrossRef]

31. Assani, A.A. Comparison of the temporal variability of maximum daily temperatures for summer months in relation to El Nino events in Southern Québec. In Exteme Weather; Sallis, P.J., Ed.; IntechOpen: London, UK, 2008. [CrossRef]

32. Assani, A.A.; Maloney-Dumont, V.; Pothier-Champagne, A.; Kinnard, C.; Quéessy, J.-F. Comparison of the temporal variability of summer temperature and rainfall as it relates to climate indices in southern Quebec (Canada). Theor. Appl. Climatol. 2019, 137, 2425-2435. [CrossRef]

33. Assani, A.A.; Landry, R.; Quessy, J.-F.; Clément, F. Temporal Variability of Rain-Induced Floods in Southern Quebec, Climate Change. In Geophysical Foundations and Ecological Effects; Blanco, J., Kheradmand, H., Eds.; IntechOpen: London, UK, 2011. [CrossRef]

34. Assani, A.A.; Landry, R.; Laurencelle, M. Comparison of interannual variability modes and trends of seasonal precipitation and streamflow in Southern Quebec (Canada). River Res. Appl. 2012, 28, 1740-1752. [CrossRef]

35. Beauchamp, M.; Assani, A.A.; Landry, R.; Massicotte, P. Temporal variability of the magnitude and timing of winter maximum daily flows in southern Quebec (Canada). J. Hydrol. 2015, 520, 410-417. [CrossRef]

36. Guerfi, N.; Assani, A.A.; Mesfioui, M.; Kinnard, C. Comparison of the temporal variability of winter daily extreme temperatures and precipitations in southern Quebec (Canada) using the Lombard and copula methods. Int. J. Climatol. 2015, 35, 4237-4246. [CrossRef]

37. Assani, A.A.; Charron, S.; Matteau, M.; Mesfioui, M.; Quessy, J.F. Temporal variability modes of floods for catchments in the St. Lawrence Watershed (Quebec, Canada). J. Hydrol. 2010, 385, 292-299. [CrossRef]

38. Mazouz, R.; Assani, A.A.; Quessy, J.-F.; Légaré, G. Comparison of the interannual variability of spring heavy floods characteristics of tributaries of St. Lawrence River in Quebec (Canada). Adv. Water Res. 2012, 35, 110-120. [CrossRef]

39. Mazouz, R.; Assani, A.A.; Rodriguez, M. Application of redundancy analysis to hydroclimatology: A case study of spring heavy floods in southern Québec (Canada). J. Hydrol. 2013, 496, 187-194. [CrossRef]

40. Smakhtin, V.U. Low flow hydrology: A review. J. Hydrol. 2001, 240, 147-186. [CrossRef]

41. Rolls, R.J.; Leigh, C.; Sheldon, F. Mechanistic effects of low-flow hydrology on riverine ecosystems: Ecological principles and consequences of alteration. Freshw. Sci. 2012, 31, 1163-1186. [CrossRef]

42. Belzile, L.; Bérubé, P.; Hoang, V.D.; Leclerc, M. Méthode Écohydrologique de Détermination des débits Réservés pour la Protection des Habitats du Poisson dans les Rivières du Québec. Rapport Présenté par l'INRS-Eau et le Groupe-Conseil Génivar inc. au Ministère de l'Environnement et de la Faune et à Pêches et Océans Canada. 1997; 83p. Available online: http:/ / www.obvcapitale.org/plans-directeurs-de-leau-2/2e-generation/diagnostic/section-3-problematiques-associeesa-la-quantite-et-a-la-securite/3-4-debits-reserves (accessed on 20 December 2020).

43. Sneyers, R. On the Statistical Analysis of Series of Observations; Technical Notes N ${ }^{\circ} 143$; World Meteorological Organization: Geneva, Switzerland, 1990; 192p.

44. Von Storch, H. Misuses of statistical analysis in climate research. In Analysis of Climate Variability; von Storch, H., Navarra, A., Eds.; Springer: Dordrecht, The Netherlands, 1995; pp. 11-26.

45. Yue, S.; Pilon, P.; Cavadias, G. Power of the Mann-Kendall and Spearman's rho tests for detecting monotonic trends in hydrological series. J. Hydrol. 2002, 259, 254-271. [CrossRef]

46. Yue, S.; Wang, C.Y. The Mann-Kendall test modified by effective sample size to detect trend in serially correlated hydrological series. Water Resourc. Manag. 2004, 18, 201-218. [CrossRef]

47. Hamed, K.H.; Rao, A.R. A modified Mann-Kendall trend test for autococorrelated data. J. Hydrol. 1998, 204, 182-196. [CrossRef]

48. Hamed, K.H. Enhancing the effectiveness of prewhitening in trend analysis of hydrologic data. J. Hydrol. 2009, 368, 143-155. [CrossRef]

49. Pettitt, A.N. A non-parametric approach to the change-point problem. J. R. Statist. Soc. Ser. C 1979, 28, 126-135. [CrossRef] 
50. Serinaldi, F.; Kilsby, C. The importance of prewhiting in change point analysis under persitence. Stoch. Environ. Res. Risk Assess. 2016, 30, 763-777. [CrossRef]

51. Lombard, F. Rank tests for changepoint problems. Biometrika 1987, 74, 615-624. [CrossRef]

52. Quessy, J.F.; Favre, A.C.; Saïd, M.; Champagne, M. Statistical inference in Lombard'S smooths-change model. Environmetrics 2011, 22, 882-893. [CrossRef]

53. Mao, D.; Cherkauer, K.A. Impacts of land-use change on hydrologic responses in the Great Lakes region. J. Hydrol. 2009, 374, 71-82. [CrossRef]

54. Tan, X.; Gan, T.Y. Contribution of human and climate change impacts to changes in streamflow of Canada. Sci. Rep. 2015, 5, 17767. [CrossRef]

55. Assani, A.A.; Landry, R.; Kinnard, C.; Azouaoui, O.; Demers, C.; Lacasse, K. Comparison of the spatiotemporal variability of temperature, precipitation, and maximum daily spring flows in two watersheds in Quebec characterized by different land use. Adv. Meteorol. 2016, 2016, 3746460. [CrossRef]

56. Muma, M.; Assani, A.A.; Landry, R.; Quessy, J.-F.; Mesfioui, M. Effects of the change from forest to agriculture land use on the spatial variability of summer extreme daily flow charactersitics in southern Quebec (Canada). J. Hydrol. 2011, 407, 153-163. [CrossRef]

57. Quilbé, R.; Rousseau, A.; Moquet, J.-S.; Savary, S.; Ricard, S.; Garbouj, M.S. Hydrological response of a watershed to historical land use evolution and future land use scenarios under climate change conditions. Hydrol. Earth Syst. Sci. 2008, 12, 101-110. [CrossRef]

58. Landry, R.; Assani, A.A.; Biron, S.; Quessy, J.-F. The management modes of seasonal floods and their impact on the relatioship between climate and streamflow downstream from dams in Quebec (Canada). River Res. Appl. 2014, 30, 287-298. [CrossRef]

59. Bullock, A.; Acreman, M.C. The role of wetlands in the hydrological cycle. Hydrol. Earth Syst. Sci. 2003, 7, 358-389. [CrossRef]

60. Ruiz, J. Modernization agriculture and agricultural land cover in Quebec (1951-2011). Cahiers Géographie Québec 2019, 63, in press (In French)

61. Perrault, L.; Haché, M.; Slivitzky, M.; Bobée, B. Detection of changes in precipitation and runoff over eastern Canada and U.S. using a Bayesian approach. Stoch. Environ. Res. Risk Assess. 1999, 13, 201-216. [CrossRef]

62. Assani, A.A.; Lajoie, F.; Vadnais, M.-E.; Beauchamp, G. Influence of the Arctic oscillation on the interannual variability of precipitation in the Saint-François river watershed (Quebec, Canada) as determined by canonical correlation analysis. J. Water Sci. (Rev. Sci. Eau) 2008, 21, 21-33. (In French) 